\title{
A Study on Development Strategy of Water Margin Martial Arts Culture
}

\author{
Degang Xu
}

\author{
Zaozhuang University, Zaozhuang Shandong, 277160 China \\ X6136866@126.com
}

Keywords: water margin martial arts culture, existing problems, development strategy

\begin{abstract}
As a kind of Chinese cultural entity, the water margin martial arts culture is the carrier of Chinese traditional sports culture with high promotional value. This article mainly focuses on the formation and development of water margin martial arts culture as well as existing problems and countermeasures in the current development process. It has profound practical significance for the transmission of Chinese sports culture and promoting traditional sports culture serving for contemporary social progress.
\end{abstract}

Since the late Northern Song dynasty, tales about 'water margin' have been widely spread among the people, generation after generation. In the context of Qilu culture, along with the wide dissemination and broad impact of the Water Margin, water margin culture has gradually formed in the relevant geographical regions. After a thousand years polish, water margin culture not only demonstrates the values and aesthetic ideals of traditional culture but also reflects the essential spirits of Chinese culture, which has become an integral part of the spiritual wealth and cultural heritages of the Chinese nation.

\section{The Formation of Water Margin Martial Arts Culture}

Martial arts culture is the focus of margin water culture. Based on Margin Water, Liangshan martial arts as the core, the spirits of hospitality, honesty and trustworthiness, loyalty and boldness are the spiritual kernel of water margin martial arts culture. Liangshan Shandong, on a par with Shaolin Henan, Wudang Hubei, and Emei Sichuan is one of four birthplaces of Chinese martial arts. Liangshan is in the southwest of Shandong province. Located in the downstream of the Yellow River and the historical confluence of Ji River and Wen River, it was once called 'swamp kingdom'. Due to multiple times of diversion and flood of the Yellow River, Liangshan water gradually expanded and formed the so-called 'Eight hundred square li Liangshan water' in Song dynasty. (One square li equals $540 \mathrm{mu}$ and approximates 36.018 hectares) Liang Shan people advocating martial arts, since ancient times, Wushu had prevailed in folklores. In the late Northern Song dynasty, heroes from all corners of the country led by Song Jiang gathering in Liangshan, they punished corruption and evil in the name of god. Later with the advent of Margin Water, their names were well known by the world and martial arts culture became an important part of traditional Chinese culture. After the failure of Liangshan uprising, representatives of Liangshan heroes such as Lu Zhishen, Wu Song, Yan Qing, Shi Qian, and Lin Chong exploring and studying martial arts with an honorable Buddhist monk Yuan Tong abbot of Jianfu temple, Kung fu of China Liangshan Meridian Gate officially formed. Buddhist monk Xi Zhu abbot of Liangshan Faxin temple and Li Qingshan peasant insurrection leader in the Ming dynasty as well as Wang Junke, Pan Shou, and Ma Shengyan in the late Qing dynasty, they were all masters of Liangshan kung fu. One after another several ancient boxing methods were introduced into Liangshan and blended with local margin water martial arts culture. Featuring ten kinds of boxing including Lianshan margin water martial arts (Liangshan Meihua boxing), Hong boxing, Shaolin boxing, and Yangqing boxing, Liangshan kung fu formed a complete system, contributing to the inheritance and development of margin water martial arts. In recent years, the local people has sorted out $\mathrm{Wu}$ Song de-handcuffed boxing, Wu Song drunken boxing, Yangqing boxing, Li Kui axing, Guan Shen broadsword, Wu Song double broadsword, Lin Chong spear and Lu 
Zhishen Staff from Margin Water, which enjoys tremendous popularity among the Kung fu enthusiasts and tourist at home and abroad.

With a clear inheritance context as well as distinct ethnic and geographical features, margin water martial arts culture has a history of over 800 years. It not only possesses some craft traditions, performance styles, competitive sports features, and folklore features but also boasts of strong and unique cultural values and considerable social influence, holding certain inheritance potential in contemporary groups. As a cultural entity of the Chinese nation, it is a carrier of traditional Chinese sports culture with high promotional value.

\section{Factors Impeding the Development of Culture of Martial Arts in the Water Margin}

\subsection{Weak Theoretical Research}

The martial arts in the Water Margin has the history of more than eight hundred years, being popular in the area of Liangshan Mountain, but because of historical reasons and constant wars, relevant theoretical materials reserved in the form of text are quite limited. In other words, in most cases, the martial arts in the Water Margin is inherited by oral teaching and personal examples while the deep research on it is relatively less. Moreover, the practice of the martial arts in the Water Margin prevails in the rural areas and the main practitioners are farmers commonly with a low cultural qualities. All of these will definitely cause the theoretical research and innovation of the martial arts in the Water Margin weak.

\subsection{Lack Reserve Personnel}

It's known that martial training will cost a lot of money and time and the trainers will suffer a lot but the effects can only be seen after a very long time and the available development chances for the trainers are very limited. That's why many parents are unwilling to send their children to learn martial arts. Even for the children who choose to learn martial arts, they tend to learn those items which have quick returns and strong practicability. Thus the number of the children who learn martial arts is becoming less and less, and if things continue this way, a dangerous situation in which there are few inheriting the martial arts in the Water Margin will occur.

\subsection{Lack publicity and education}

The publicity and education from the local educational and cultural departments are inadequate. To be concrete, the text, video and picture concerning the culture of the martial arts in the Water Margin are quite less both in schools and in the society. And the materials on the culture of the martial arts in the Water Margin collected and sorted out carefully by the local cultural workers have not been accepted by common people, which makes many people have no idea about what the culture of the martial arts in the Water Margin is. Although the local related departments, in order to solve the problems mentioned above, have taken some proactive measures, for examples, they have established some martial arts schools in which Songjiang Martial Arts School and Caozhou Martial Arts Institute are the most famous ones; they have also made the performance of martial arts in the Water Margin a program of the Spring Festival Gala and they have created a teleplay called Water Marine Boy, the force and the breadth of the publicity are not enough and the spread of the culture of the martial arts in the Water Marine lacks overall planing and scientific publicity.

\subsection{Development of Martial Arts Lacks Innovation and are Backwards in the Request of the Times}

The main aims of the development of the martial arts in the Water Marine are strengthening the body and learning attacking and defense. The learners must acquire the basic martial arts skills before they can learn to attack and defense. Martial training is a long and difficult path which will take the persistent learners a long time to reach the requirement and even reach a certain level of attacking. Naturally, it violates the modern fast-paced and high-efficient life pattern and is hard to be accepted by the young generation. Besides, although the inherent regulations of some folk martial arts institutions can, to some extent, protect items' purity and continuity, they have the characteristics of being exclusive, conservative and stubborn. What's more, there is certain limitation of education and weak cultural environment. All of these factors make the advanced scientific and technological 
facilities and technologies fail to be referenced and introduced. In a word, low technological content, to a certain extent, influence the development and innovation of the martial arts in the Water Marine .

\subsection{Disordered and Excessive Research and Development of Cultural Resources}

Some local governments spend huge amount of money in creating the industries concerning the Water Marine, which causes a bad quality, reconstruction as well as waste. What some merchants do, in fact, is totally without any connection with the Water Marine. These actions show that they are anxious to seek short-term successes and get quick profits, but the spiritual core of the culture of the martial arts in the Water Marine as the intangible cultural heritage is overlooked. Nowadays, the culture of the martial arts in the Water Marine is strongly influenced and challenged, hence it is losing the vitality and becoming less and less important.

\section{The development strategy of the Water Margin Wushu Culture}

The Water Margin Wushu Culture as a non-material cultural heritage, though not a modern social product, seems to be leaving away from modern life, but it is the essence of Chinese civilization, and is a treasure of national culture. Thus, to protect and inherit it, and to promote its development, can not only provide the spiritual support for the construction of the harmonious society, but also play a certain role in carrying forward the national culture and promoting cultural globalization. Therefore, vigorously promote the function and value of the Water Margin Wushu Culture to draw the attention and enthusiasm of the whole society, and to call on the active participation of the majority of the people to protect and inherit, and quicken the speed of reasonable and sound development is of great significance.

\subsection{Establish the system of inheritance and standardize the treatment and obligation of the inheritors}

The main force of the inheritance and development of the Water Margin Wushu is the people. Since there are many schools of the Water Margin martial arts, the government should develop relevant rules and regulations to establish inheritor of each school and scientific and strict inheritance system. Many inheritors come from the folk, even rural areas. Some of them are older, some have no high culture level, some have no formal occupation, some struggle against life difficulties, but all of them are an important figure in the development of the Water Margin Wushu and need protection and support of the government. So relevant departments should standardize treatment and obligations of inheritors, form mechanisms of grade assessment of selection, learning and skill, employment orientation, exit, so that the inheritor can enjoy not only the material benefits but also the spiritual recognition and attention. More important, it makes spreaders aware of their own value and the significance of the inheritance and development of the Water Margin Wushu. Establish a scientific system of inheritance can also eliminate blind expansion, and focus on the development of the spirit core. Pay attention to the spiritual kernel development of the Water Margin Wushu Culture to make it sustainable development, possess exuberant vitality, to make the Water Margin Wushu smoothly transmit but meanwhile continuously innovate, so that the ancient martial art can be revitalized.

\subsection{Government led, strengthen publicity}

Liangshan is the birthplace of Qilu martial arts culture, known as "the hometown of martial arts", and is nourished by the heavy Qilu culture. More than 800 years, something related to " the Water Margin" has stepped out of Shandong to the country and the world. With the internationalization of regional economy and traditional sports, the Water Margin Wushu with its distinctive characteristics and unique social influence makes its advantages become more prominent. So governments at all levels can take advantage of the excellent opportunities for development to promote the Water Margin Wushu Culture market-oriented, so that it can be from closed to open, from automorphism to competition. Government should use a variety of ways to vigorously disseminate, promote the connection and integration of the Water Margin Wushu Culture with other cultures, accelerate the pace of the Water Margin Wushu Industry opening to the outside to expand its influence and improve industry overall service and competitiveness capacity. 


\subsection{Give full play to the advantages of school education, inhance the publicity}

In addition to the construction of the necessary military school, the government should introduce the martial arts into school sports education, such as all types of schools at all levels vigorously promote martial arts knowledge, set up a number of relatively simple martial arts course, invite martial arts inheritors to perform site demonstration teaching or give lectures, hold activities and games related to martial arts etc.. And some high level of martial arts school can set up training base, select and train Wushu athletes, improve coaches' quality, actively carry out sports-related intercommunicative activity,so that continuously improve the overall level of martial arts talents. Meanwhile, the government take the school as the basis, and radiate to the whole society, to publicize the martial arts, teach martial arts, so as to let the whole society be aware of the importance of the Water Margin Wushu.

\subsection{Integrate with regional economy like sports tourism, form a win-win situation}

Wushu, as a traditional sports project, not only has combat function and fitness function, but also possesses ornament and entertainment value, which has laid a solid foundation for the Water Margin Wushu performance to be industrialization. Liangshan is the birthplace of the Water Margin story, and is rich in tourism resources among which have water margin cultural relics such as Song Jiang's hometown water fort, Akira hometown Dong Xi Countryside, Wu Yong Science Museum, Sun Erniang Inn and so on. The local government can establish sports tourism with the Water Margin Wushu as focus to integrate the Water Margin Wushu Performance with visiting the Water Margin relics or enjoying the water margin story performance etc., and at the same time linking to various forms of tourism around, such as Heze Peony Festival, muount Yu Taishan, visit Qufu etc, to form tourism culture this chain. Therefore, this can closely integrate study and development of the value of the tourism industry and the Water Margin culture to achieve cultural and economic win-win benefits.

\subsection{Strengthen the Theoretical Research and Promote the Connotative Development}

In the process of the development of the martial arts of Water Margin, it is transmitted merely through the way of word-of-mouth and only martial arts skills are passed on due to the limitation of specific social background and historical condition. And the lack of systemic data to a large extent limits the development of the martial arts of Water Margin. Therefore, it's necessary to strengthen the theoretical research of the martial arts of Water Margin and open up innovation continuously. The departments concerned can organize experts and scholars to carry on rescuing excavation and arrangement on certain sorts of Quan and comprehensive theoretical research on the martial arts of Water Margin so as to keep the essence and reject the dross, combine traditional martial arts and modern sports, as well as reform and innovation on the basis of inheritance and absorption.

\section{Conclusion}

In short, we should protect and inherit the culture of the martial arts of Water Margin, effectively promote its development, explore the scientific and normative inheritance system, and pay attention to the construction of the spiritual essence, accelerating the marketization of the martial arts of Water Margin. Combine tourism and the cultural value research and development of the martial arts of Water Margin together to achieve win-win benefits of culture and economics. Combine the competitive character and the ornamental value of martial arts, the martial arts of Water Margin and the stories of Water Margin, martial arts performances and the remains of Water Margin, Liangshan and local martial arts, and the martial arts of Water Margin culture and other culture together to expand its influence and enhance the overall service capacity and competitiveness of the industry, thus managing to build big Water Margin cultural system. All of these above are practically significant to the spreading of Chinese sports civilization and the promotion of service capacity of the traditional ethnic sports culture for the development of contemporary society.

Foundation Items: the financial aid of scientific research development plan in Universities from Shandong Provincial Department of Education, Shandong Provincial Department of Finance in 2014(number J14WK04) 


\section{References}

[1]Li Chengyin. Research of the Traditional Martial Arts Culture in Shandong[M]. Beijing: Beijing Sport University Press 2009.

[2]Song Yixiang. Liangshan Kung Fu[M]. Shandong: Shandong Friendship Press 1994.

[3]Yi Chengmin, Li Yanmeng. The Discussion of Related Concepts of the Martial Arts Culture of Water Margin[J]. Fight • Martial Arts Science Vol. 9, no. 5, 2012

[4]Li Chengyin. Meridian Gate Kung Fu and Culture of Qi and Lu[J]. Sports Culture Guide 2002.2

[5]Liu Fushun, Liu Ruilian. Analysis and Rational Thinking of the Martial Arts Culture[J]. Shandong Physical Education Institute Vol. 27, no. 8, 2011.

[6]Liu Fushun, Mu Ruili. The Inheritance and Development of the Martial Arts of Water Margin[J]. Sichuan Sports Science 2010. 4.

[7]Yang Youfeng. The Research of the Martial Arts Cultural Development of Water Margin[J]. Journal of Sports Adult Education Vol. 28, no. 6, 2012

[8]Mu Ruili, Liu Fushun. Development Strategy of the Martial Arts Culture of Water Margin[J]. Fight . Martial Arts Science Vol. 7, no. 5, 2010

[9]Ma Yongtong. Liangshan Martial Art and its cultural characteristics[J]. Journal of Jilin Institute of Physical Education Vol. 26, no. 6, 2010 